\title{
PARAMETERS FOR THE STANDARDIZATION OF CHLOROPHYLL AND ASSESSMENT OF PS II QUANTUM EFFICIENCY FOR AVOCADO (Persea americana Mill)
}

\author{
PARÂMETROS PARA A ESTANDARIZAÇÃO DE ÍNDICES DE CLOROFILA E DA \\ EFICIENCIA QUANTICA DO PS II EM ABACATEIRO (Persea americana Mill)
}

\author{
Edwin Antonio Gutierrez RODRIGUEZ ${ }^{1}$; Mauricio Panizzi PENARIOL ${ }^{2}$; \\ Pedro Luis Alves da Costa AGUIAR ${ }^{3}$, Rita de Cassia PANIZZI ${ }^{4}$; \\ Renata Aparecida de ANDRADE
}

1. Agronomist, Ph.D., Fellowship COLCIENCIAS, edunillanos@ hotmail.com; 2. Fellowship Plant production Department; 3, 4, 5. Ph.D Professor State University of Sao Paulo (UNESP), Jaboticabal, SP, Brazil;

\begin{abstract}
The standard physiological parameters for assessing stress physiology, of plants, such as chlorophyll index and photosystem II fluorescence, are essential for measuring reactions of plants to stress conditions. To help standardize the parameters for chlorophyll indices of chlorophylls $a, b$, and total and the fluorescence of photosystem II (Fv/Fm), which are physiological indicators of stress conditions, 6-mo-old seedlings of Persea americana Mill. cv. 'Duke7' and 'Toro canyon', were evaluated under shade house conditions. For each plant, chlorophyll indices were measured from the second through the fourteenth fully expanded leaves. Fluorescence was measured in the third, fifth, seventh, and ninth fully expanded leaf, and determined in function of both, time and intensity of the exposure light source, and the time for dark pre-acclimation of the leaf; was also compared right and left sides of the leaves. Chlorophyll indices were not different between the left and right sides of the leaves, but were different between varieties with 'Duke 7' having the highest value from the eighth leaf, while leaves tested for 'Toro canyon' did not show a difference. For Fv/Fm, there was an interaction among the three factors in both cultivars. A prolonged exposure time (nine seconds), short time for acclimation to darkness, and low intensity of exposure did not induce maximum fluorescence levels. On both avocado cultivars, exposure to maximum light intensity for 7 seconds after 25 to 30 minutes of acclimation to darkness, was the most favorable combination allowing the measurement of photosynthetic efficiency.
\end{abstract}

KEY WORDS: Avocado. Chlorophyll index. Fv/Fm. Photosystem II. Physiological parameters.

\section{INTRODUCTION}

Avocado (Persea americana Mill), a C3 plant (WENG; LAI 2005) with spiral leaf arrangement during seedling stage, is native from subtropical and tropical areas in Central and South America having some differences according the origin area. Among them, differences in leaf characteristics such as pubescence, leaf thickness, and concentration of chlorophyll, are important characteristics affecting the efficiency of light harvesting and photosynthesis (MANDEMAKER 2008)

Three botanical varieties of avocado are recognized: Persea americana Mill. var. americana 'West Indian'; var. guatemalensis L. Wms., and var. drymifolia Blake 'mexicana' (ASHWORTH, 2003; SCORA; BERGH, 1990). They differ in adaptive strategies for responses to biotic and abiotic limiting factors (ASHWORTH, 2003) involving genetics variations in growth and chlorophyll content, among others, (SCHAFFER; WHILEY 2003).

Abiotic factors such as salinity, root hypoxia, and extreme temperatures are potentially limiting or devastating (OYARCE; GUROVICH 2010, SCHAFFER ET AL. 2013), however biotic factors, such as diseases caused by Rosellinia necatrix Berl., Raffaelea lauricola T.C. Harr. and Phytophthora cinnamomi Rands. are potentially limiting, being $P$. cinnamomi the most devastating oomycete in avocado commercial crops (GEORGE 1956, GABOR 1991, DOUHAN ET AL. 2011).

According with the previously, between the three races, $P$. americana var. drymifolia is considered more adapted to low temperature while var. americana and guatemalense have tolerance to $P$. cinnamomi Rands. The Mexican rootstock varieties, 'Topa-topa', and 'Dusa' are susceptible to Rosellinia sp., and highly tolerant to $P$. cinnamomi (FERRI-MARTINEZ et al. 2016).

Biotic and abiotic stresses induce physiological variations trough signaling responses, gene expression, and photosynthetic efficiencies such as photosynthetic metabolism reduction: for example, moderate irradiance can affect photooxidative reactions (PAPAGEORGIOU 2004, TSIMILLI-MICHAEL; STAMATAKIS 2007, BJÖRN ET AL. 2009). 
To measure physiological variations resulting from stress responses, in situ techniques can be used (OYARCE; GUROVICH 2010, ASHRAF; HARRIS 2013, SARWAT ET AL. 2013). These techniques can also help in determining initial responses, which are useful for the early disease detection (MARTÍNEZ-FERRI et al. 2016). The quantum efficiency of photosystem II (fluorescence ratio) and the chlorophyll index are the most commonly used in situ techniques for nondestructive evaluation (BAKER 2008).

Fluorescence can be determined by induction with modulated or continuous light being the latter more accurate determining efficiency in photosystem II and is easily adaptable to in situ conditions (Moreno et al. 2008). The ratio (Fv/Fm) between the maximum fluorescence $(\mathrm{Fm})$ and the variable fluorescence $(\mathrm{Fv})$ is important for determining the quantum efficiency of photosystem II through electron transport rate (MORENO ET AL. 2008, ASHRAF; HARRIS 2013;).

The value of $\mathrm{Fv} / \mathrm{Fm}$ depends on factors such as the length of the leaf before dark acclimation, the duration and intensity of light exposure, and chlorophyll content ( HALL; RAO 1999, WENG; LAI 2005, BUCHNER ET AL. 2013). These factors may vary among and within a species or cultivar, for example, with $P$. americana ' Duke 7 'and 'Toro canyon'.

Quantifying photosynthetic pigments as chlorophylls a, b and total can be performed by extracting them in organic solvents followed by analysis in a spectrophotometer (KHACHIK et al. 1986) or by indirectly using a chlorophyll meter (RICHARDSON et al. 2002). The ratio of chlorophyll $\mathrm{a} / \mathrm{b}$ is considered a measure of the light harvesting antenna size where $a / b>4$ indicates a small PSII antenna (Matsubara et al. 2011) which is characteristic of a sun-adapted leaf. However, low ratio of Chlorophylls a/b $(<4)$ suggests a higher RuBisCO concentration and collecting stacking thylakoids. At the same time, in conditions of high irradiance, increasing in $\mathrm{Chl} \mathrm{a} / \mathrm{b}$ ratio suggests the decrease in chlorophyll PS II and increment in PS I (REED et al. 2012).

Based on previously mentioned and due to the lack of parameters for photosynthetic efficiency $(\mathrm{Fv} / \mathrm{Fm})$ and for chlorophyll index measuring. Hence, the objective of this study was to establish parameters that can be used to develop a protocol for evaluation of these characteristics in situ for avocado seedlings.

\section{MATERIAL AND METHODS}

At the the Universidade Estadual Paulista, Faculdade de Ciências Agrárias e Veterinarias, Jaboticabal, (SP-Brazil) $\left(21^{\circ} 15^{\prime} 17 \quad\right.$ "S, $48^{\circ}$ 19'20"W), between May and June, healthy seeds of avocado, P. americana 'Duke 7' and 'Toro canyon', were obtained from one open-pollinating tree located in the germplasm bank.

The seeds were disinfected with sodium hypochlorite $(\mathrm{NaOCl}) 1 \%$ (a.i.) for 30 minutes, and a 1-in portion from the apex seed was removed. Then, the seeds were sown in pots containing two liters of the commercial substrate Plantmax ${ }^{\mathrm{TM}}$ previously sterilized with vapor heat, then, placed and maintained in a shade house $\left(53.42 \mu \mathrm{mol} \mathrm{m}^{-2} \mathrm{~s}^{-1}\right.$ and $22 \pm 0.9^{\circ} \mathrm{C}$ ). The plants were irrigated daily and no fertilizer or pesticides were used.

Each experimental unit consisted of seven 6-mo-old plants, without visible signs of stress, and in a factorial arrangement with a completely randomized design. The quantum chlorophyll index and efficiency of photosystem II were each evaluated.

A chlorophyll meter (Falker, mod. ClorofiLOG) was used to measure chlorophyll indices from the $2^{\text {nd }}$ to the $14^{\text {th }}$ fully expanded leaf in basipetal direction. Each replication involved four measurements taken on both, right and left leaf side. The chlorophylls a/b ratio was calculated.

To determine the quantum efficiency of photosystem II $(\mathrm{Fv} / \mathrm{Fm})$, variables were analyzed as follows in a $6 \times 6 \times 4$ factorial arrangement: 6 dark acclimation time $(5,10,15,20,25$, and $30 \mathrm{~min})$, six light exposure intensities $(50,60,70,80,90$, and $100 \%)$, and four light exposure times $(3,5,7$, and 9 seconds).

A portable flurometer was used to measure the fluorescence (Hansatech, mod.PEA MK2, Company, City, State, Country). This had a unit combining sensor-and lighting, with the latter providing red light $\left(560 \mu \mathrm{molm}^{-2} \mathrm{~s}^{-1}\right)$ for each $4-\mathrm{mm}^{2}$ leaf area.

In order to quantify fluorescence efficiency, were measured F0, Fm and the Fv/Fm ratio; where: $\mathrm{F} 0=$ initial fluorescence, $\mathrm{Fm}=$ maximum fluorescence and $\mathrm{Fv}=$ variable fluorescence $(\mathrm{F} 0$ Fm) (Oquist \&Wass 1988). Measurement of F0, $\mathrm{Fm}$, and $\mathrm{Fv} / \mathrm{Fm}$ were performed within the plant profile and on the right and left sides of the surface of seventh leaf. Before measurement, the leaves were provided with 25 minutes of dark acclimation and $100 \%$ light intensity for 7 seconds.

The color spectra for $P$. americana leaves were analyzed for, both, 'Toro canyon' and 'Duke 7'. 
The leaves were collected from upper to lower direction on the plants and scanned using the Image Scanner IIITM. The images were analyzed with Image Master Software 2D Platinum ver. 7.0 TM, using a green-blue filter.

Means were compared using factorial ANOVA and-regression analyze was adjusted when difference was significant .

\section{RESULTS}

\section{Chlorophyll index in the plant profile}

Values for the chlorophyll index in the plant profile of 'Duke 7' increased with the leaf maturity while those in 'Toro canyon' remained constant. 'Duke 7' showed higher indices for chlorophyll a, b, and total from leaves 9 to 14 without difference between these (Figure 1) while, in TC was not different, in total chlorophyll $(\mathrm{p}=0.83)$, chlorophyll $\mathrm{a}(\mathrm{p}=0.72)$, and chlorophyll b $(\mathrm{p}=0.84)$. In 'TC' seedlings, the mean chlorophyll indices were 37.3 $(\mathrm{cv}=8.65 \%), 13.8(\mathrm{cv}=20.84 \%)$, and $51.1(\mathrm{cv}=$ $11.30 \%$ ), for chlorophylls a, b, and total, respectively.

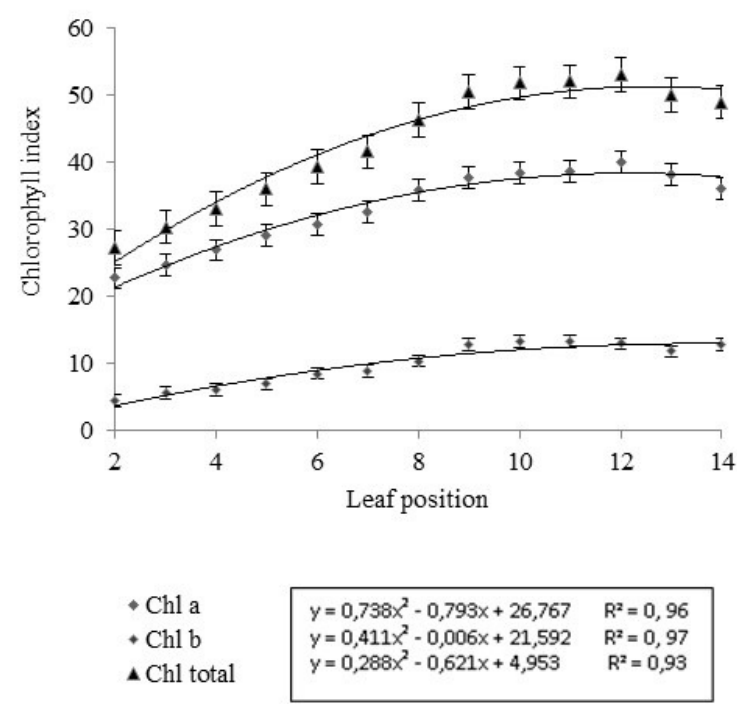

Figure 1. Regression analysis of chlorophyll index in the profile of P. americana seedlings cv. 'Duke 7'.

In leaves of 'Toro canyon', the mean ratio for chlorophyll indices $\mathrm{a} / \mathrm{b}$ was 2.7 and did not differ significantly among leaves in the plant profile. However, leaves of 'Duke 7' exhibited a negative quadratic relationship with a mean 4.96 for the second leaf, and the ratios and decreased as the leaves become older, with 2.8 in leaf $14^{\text {th }}$ (Figure 2).

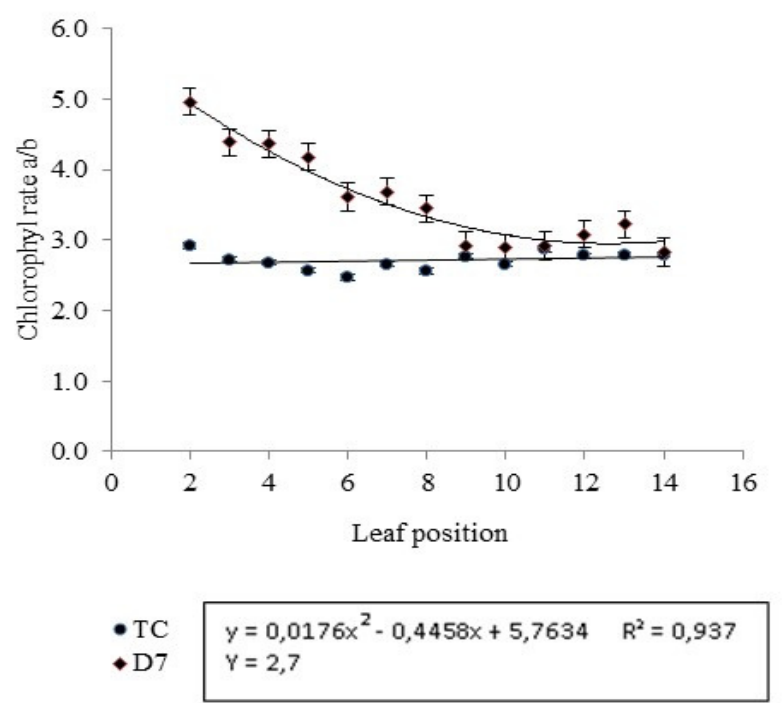

Figure 2. Regression analysis of chlorophyll a/b ratio in the profile of seedlings of $P$. americana 'Toro Canyon' (TC) and 'Duke 7' (D7). 
There was variation in the color and the spectrum of leaves trough the profile. The spectrum of 'Toro canyon' leaves was more homogeneous through the plant profile, while for 'Duke7' leaves, become more homogenous from the eight leaf (Figure 3)

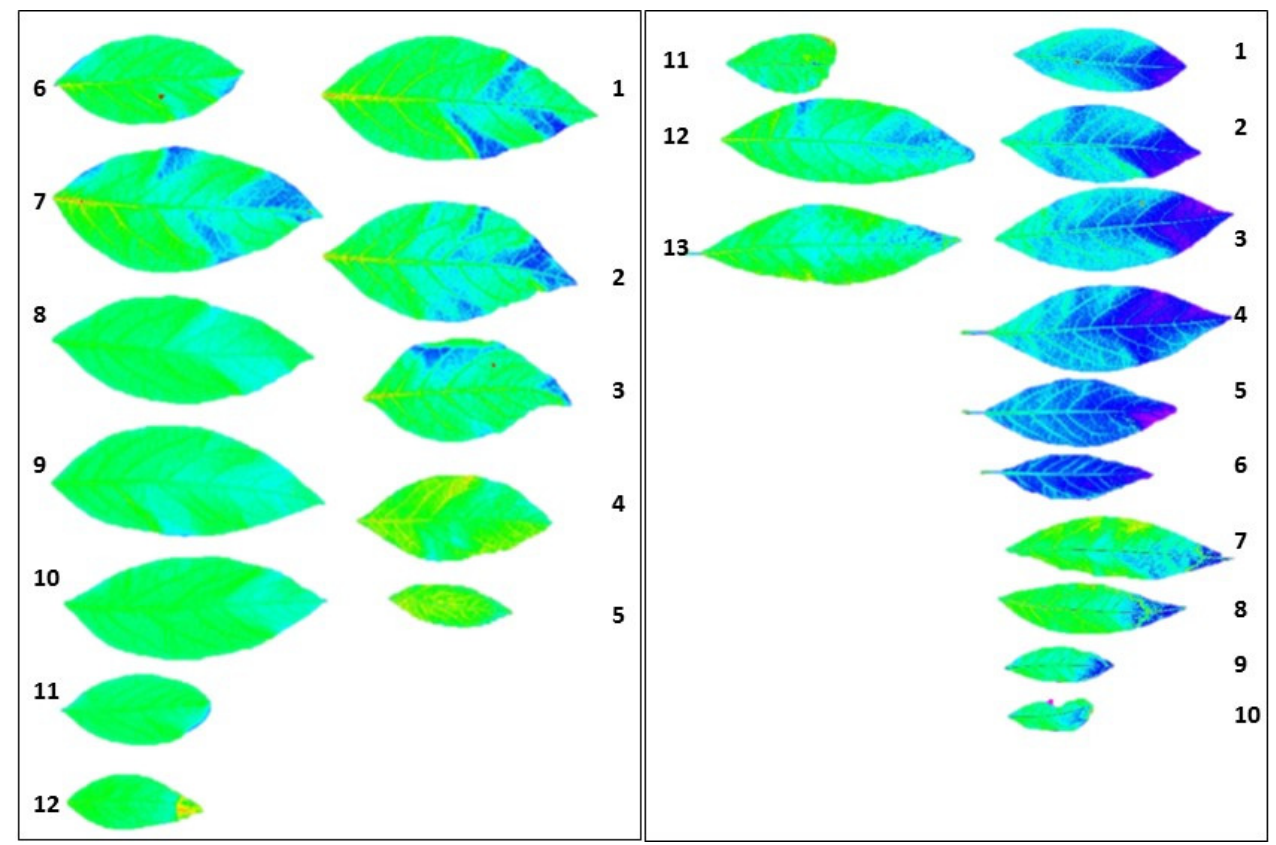

Figure 3. Leaf color spectra for Persea Americana 'Toro canyon'(left) and 'Duke 7'(right) scanned with Image Scanner III ${ }^{\mathrm{TM}}$ and analyzed with Image Master software 2D Platinum ver. 7.0 ${ }^{\mathrm{TM}}$. Numbers indicate leaf positions indicating in basipetal direction.

\section{Instrument parameters for determining photosynthetic efficiency}

For 'Duke7' (Table 1) and 'Toro canyon' (Table 2), there was significant interaction between the three factors: light exposure time and intensity with the dark acclimation time, on the Fv/Fm ratio.
The exception was for the 'Duke 7', in which the interaction between light intensity and exposure time was not significant, although variation in the photosynthetic efficiency with light intensity was independent of exposure time.

Table 1. Analyses of variance for the main effects and interactions between light intensity, time of dark acclimation, and light exposure time for determining photosynthetic efficiency $(\mathrm{Fv} / \mathrm{Fm})$ in $P$. americana 'Duke7' seedlings.

\begin{tabular}{ll}
\hline Variance source & F \\
\hline Light intensity (A) & $67.50^{* *}$ \\
Time of dark acclimation $(\mathbf{B})$ & $79.25^{* *}$ \\
Time of light exposure (C) & $21.45^{* *}$ \\
AxB & $4.15^{* *}$ \\
AxC & $1.49 \mathrm{~ns}$ \\
BxC & $14.11^{* *}$ \\
AxBxC & $1.65^{* *}$ \\
\hline SD & 0.014 \\
C.V $(\%)$ & 1.85 \\
\hline
\end{tabular}

** indicate significant differences according to Tukey's test $(\mathrm{P} \leq 0.01)$. 
Table 2. Analyses of variance for the main effects and interactions between light intensity, time of dark acclimation, and of light exposure time for determining photosynthetic efficiency $(\mathrm{Fv} / \mathrm{Fm})$ in $P$. americana 'Toro canyon' seedlings.

\begin{tabular}{lc}
\hline Variance source & F \\
\hline Light intensity (A) & $74.07 * *$ \\
Time of dark acclimation $(\mathbf{B})$ & $63.43 * *$ \\
Time of light exposure to light $(\mathbf{C})$ & $21.06 * *$ \\
& \\
AxB & $2.33 * *$ \\
AxC & $10.72 * *$ \\
BxC & $1.80 *$ \\
AxBxC & $3.15 * *$ \\
\hline SD $(\%)$ & 0.015 \\
\hline C.V $(\%)$ & 1.90 \\
\hline
\end{tabular}

** indicates significant differences according to the Tukey test $(\mathrm{P} \leq 0.01)$.

For 'Duke 7' seedlings, 25-30 min of dark acclimation resulted in a high $\mathrm{Fv} / \mathrm{Fm}$ ratio; but it was dependent on the other factors (Figure 4). When the leaves were pre-adapted for 25-30 min, there was no difference among light exposure times.

Increasing light intensity resulted in a significant difference when compared into the time

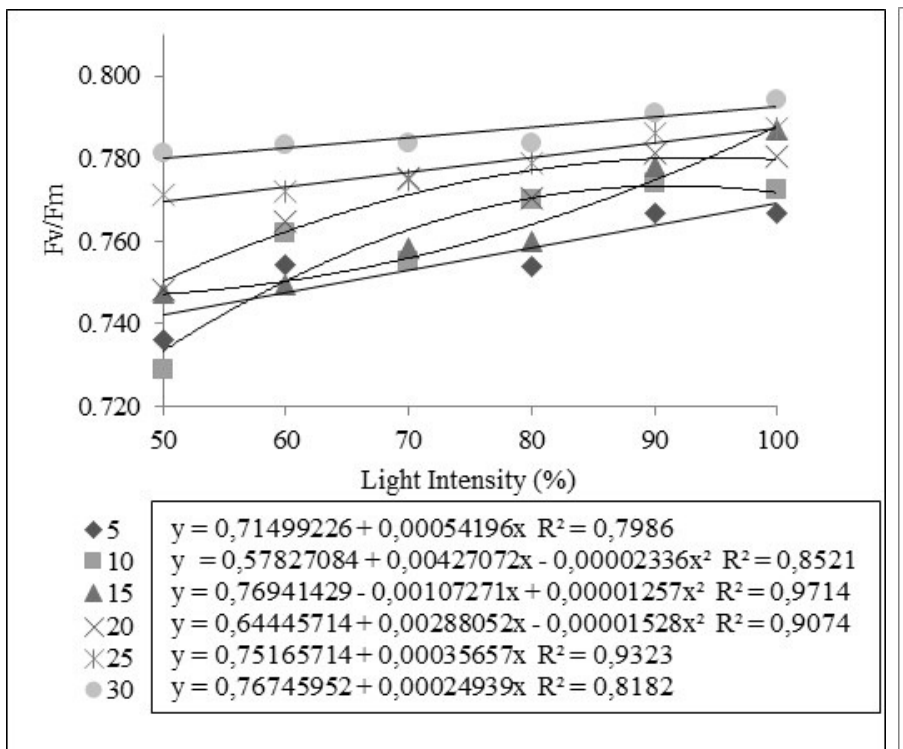

of dark acclimation. When the leaves were preadapted between 5 and 10 minutes and used 60 to $100 \%$ of light intensity were not difference, but when the pre-acclimation was increased, the Fv/Fm ratio increased simultaneously. So, for 30 minutes of pre-acclimation and $60-100 \%$ of light intensity, the interaction was no significant (Figure 4a)

Figure 4. Regression analysis for components with interaction: (a) time of dark acclimation $(5,10,15,20,25,30$ min.) and light intensity on $\mathrm{Fv} / \mathrm{Fm}$; (b) time of dark acclimation and light exposure time $(3,5,7,9$ sec.) on Fv/Fm, in Persea Americana 'Duke 7'.

Comparing into exposure time and light intensity, there was no significant interaction. However, the higher photosynthetic efficiency was reached at an exposure time of $5-7$ sec combined with 90 or $100 \%$ light intensity.

The previous behavior, could be similar, when compared the interaction between light exposure time and pre-dark acclimation of leaf, the
$\mathrm{Fv} / \mathrm{Fm}$ increased as a function of dark acclimation time. (Figure $4 b$ ).

For 'Toro canyon' seedlings, the lowest time of dark acclimation when compared into the intensity of light, limited the fluorescence stimulation. On the other hand, regardless of the dark acclimation time, when light intensities increased from 50 to $100 \%$, the $\mathrm{Fv} / \mathrm{Fm}$ showed a positive linear relationship. (Figure 5a). 


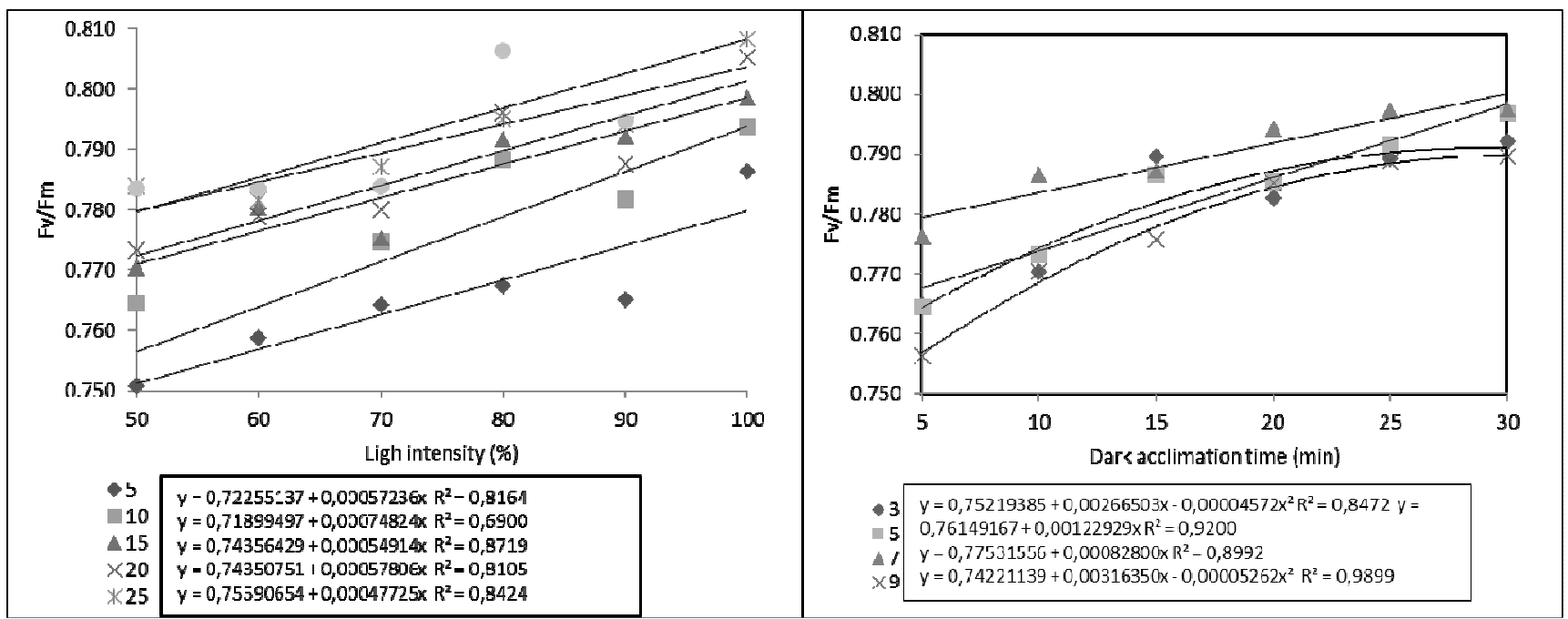

Figure 5. Regression analysis of a factorial yielding interaction between: (a) dark adaptation time and light exposure time (3,5,7,9 sec.). (b) Time of dark acclimation $(5,10,15,20,25,30 \mathrm{~min}$.) and light intensity; on photosynthetic efficiency (Fv/Fm) in P. americana 'Toro canyon' seedlings.

In the same way, the lowest time of light exposure and lighting for nine seconds using the highest intensity did not reflect high Fv/Fm.
Furthermore, the maximum fluorescence was observed with $90-100 \%$ light intensity after 7 seconds of light exposure (Figure 6).

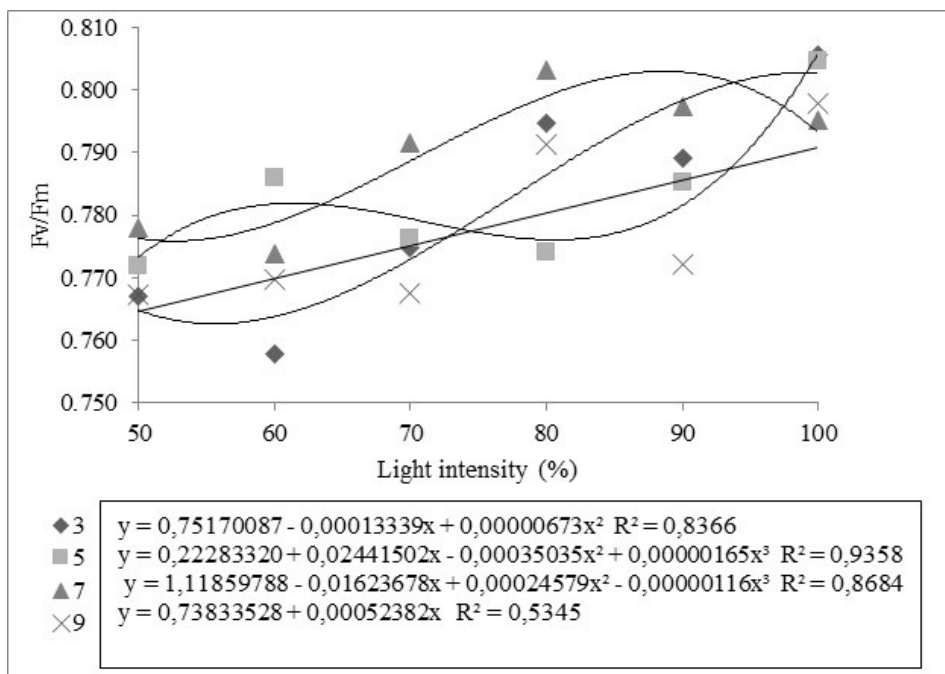

Figure 6. Regression analysis for the results of a factorial yielding interaction between light exposure time $(3,5,7,9 \mathrm{sec}$.$) and light intensity for determining photosynthetic efficiency (\mathrm{Fv} / \mathrm{Fm})$ of $P$. americana 'Toro canyon' seedlings.

The significant interaction between darkness acclimation time for leaves and lighting time suggested that minimizing darkness time limits the effectiveness of the measurement. Also, regardless of exposure time to light, when increased darkness acclimation times led to higher $\mathrm{Fv} / \mathrm{Fm}$ values, resulting from acclimation times of $25-30 \mathrm{~min}$ (Figure 5b). In either of the two cultivars, there was no difference in photosynthetic efficiency between the right and left sides of the leaf with each side yielding a mean of $0.737(\mathrm{cv}=4.13 \%)$.

\section{DISCUSSION}

\section{Chlorophyll index in the plant profile}

Indicators of leaf photosynthetic capacity, such as chlorophyll content, $\mathrm{CO}_{2}$ assimilation, and fluorescence, vary with the environment and plant characteristics, such as the age and position of the leaf (Hall \& Rao 1999). In avocados these leaf characteristics are highly influenced by weather conditions and plant growth (WOLSTENHOLME; WHILEY 1999, OUMA 2007,). 
According with the differences between the two avocado cultivars with their presumably different genomes, according with Menge et al. (2012) suggest variation in the efficiency for harvesting energy, as observed in 'Duke 7' who additionally has darker green foliage on adaxial face as strategy to improve light harvesting (STAUFFER 1986). The fact than in this study the ninth leaf yields the highest chlorophyll index, whereas 'Toro canyon' had minimal differences between these leaves additionaly indicates difference in leaves maturity.

In P. Americana, Guatemalan and Mexican races have dark green foliage with relatively light abaxial and darker adaxial leaf surfaces, with the color difference possibly evolving to aid in light interception (WOLSTENHOLME; WHILEY 1999). The pigmentation is associated with chlorophylls, carotenoids, other pigments, and accessories that vary with factors such as leaf age, position, nutritional status, and biotic stress. Here, the intensity of green color can indicate chlorophyll content thus photosynthesis ability (TAIZ; ZEIGER 2010).

Chaves (1994) using tobacco leaves similarly reported that changes in pigments may be associated with changes in photosynthetic activity, explained by the number of stomata and chloroplasts per unit of area and the ribulose-1, 5bisphosphate carboxylase/oxygenase (RuBisCO) activity, being that increased moving up in the plant to the sixth leaf, then decreased (CHAVES 1994).

According to Wolstenholme and Whiley (1999), in addition to having chlorophyll and providing sites of photosynthesis, avocado leaves with high concentration of chlorophyll $b$ are functionally important since the pigmentation is associated with photo protection of the photosynthetic apparatus. In the same way, small and homogeneous green leaves, as well as short internodes, typically of West Indian race, are associated with evolutionary environment limited by the irradiance.

\section{Photosynthesis efficiency}

The leaves of avocados are considered short-lived (10-12 months) causing a rapid turnover and physiologically they have a low light saturation point (SCHAFFER; WHILEY 2003, WOLSTENHOLME 2003). However, various authors differ in estimating photosynthetic efficiencies from avocado seedlings. For example, comparing two avocado cultivars, for transpiration, stomatal conductance, and $\mathrm{CO}_{2}$ assimilation, under stresses caused by $P$. cinnamomi and flooding the plants were pre-adapted to darkness for 30 minutes and measured on the fifth expanded leaf (PLOETZ; SCHAFFER 1987) . Furthermore, Wolstenholme and Whiley (1999), did not provide descriptions of parameters measured for chlorophyll fluorescence when they used it as an stressful temperature under orchards conditions .

In the present study, 'Duke 7' seedlings with nine seconds of light exposure showed decreased photosynthetic efficiency values, suggesting that, using these parameters, the photosystems became saturated. By contrast, when provided with lower light saturation and shorter dark acclimation times, fluorescence parameters were lower than with exposures of $90-100 \%$ of maximum lighting.

High light saturation during short periods in darkness pre-adapted leaves can over-saturate the ability of the photosystem for electrons transport without this represent the maximum fluorescence potential (Fm) (PAPAGEORGIOU 2004). Similarly, constant lighting at high intensity causes a decrease in initial (F0) and maximal (Fm) fluorescence (PAPAGEORGIOU 2004). According with this information, we observed that when lighting time was assessed, in 'Duke 7' and 'Toro canyon' the maximal Fv/Fm reached was subject to the saturation intensity.

According to Papageorgiou (2007), when the lighting does not reach an intensity sufficient to saturate, the fluorescence will reach a peak, which does not correspond to the maximum fluorescence signal (Fm) of photosystem. Relating to the time required for darkness acclimation for direct measurement of the fluorescence, according with Moreno et al. (2008) this step allows the reduction of the reaction center of photosystem II (PS II) to assess the behavior after saturating, being commonly used between 10 and 30 minutes before light exposure for 1 to 10 seconds.

In this study, for each darkness acclimation, comparing the intensity and lighting time, was obtained a peak in the fluorescence, however, receiving $25-30 \mathrm{~min}$ of acclimation, appeared optimal with both avocado cultivars.

According to Schaffer and Whiley (2003), when plants are adapted to the darkness, with the PSII system "closed", the duration of the phases for maximal fluorescence is dependent to local lighting conditions: leaves growing in the shade need a higher irradiance to saturate the entire canopy compared with leaves exposed to full sun.

Finally, for both cultivars, exposure at $100 \%$ irradiance for 7-9 seconds before dark acclimation for 25 - 30 min resulted in the highest $\mathrm{Fv} / \mathrm{Fm}$ values (0.790 -0.800). According with Ashraf and Harris 
(2013), in healthy leaves, the Fv/Fm ratio is usually about 0.800 for most plant species. Lower values may result from photo inhibition caused by stress (ALVES et al. 2002, BAKER 2004, VAZ; SHARMA 2011, ZLATEV 2014).

\section{CONCLUSIONS}

Among the 'Duke 7' and 'Toro canyon' seedlings, there were differences in chlorophyll indices and photosynthetic efficiencies. Determination of chlorophyll indices (Chlorophylls $\mathrm{a}, \mathrm{b}$, and total) on 'Duke 7' was best performed from the eight leaf and For 'Toro canyon', there was no difference among leaves.

The highest $\mathrm{Fv} / \mathrm{Fm}$ value for each cultivar, could be performed equally in either the left or right side of the leaf, at $90-100 \%$ light intensity, 7 seconds of light exposure, and after 25 -30 min of darkness acclimation, suggesting be most adequate combination when measuring photosynthetic efficiency.

\section{ACKNOWLEDGMENTS}

We thank the Corporación Colombiana de Ciencia, Tecnologia e Innovación- COLCIENCIAS (Colombia) for funding the present study, which included granting a scholarship to the first author. We also thank Flor C. Chacaltana and Fabio T. Leal for technical assistance and and to the Dr. Cliff G. Martin of Tropical Research and Education Center (TREC), University of Florida, for the English reviewing.

RESUMO: Os parâmetros padronizados para avaliação do estresse fisiológico de plantas, tais como índice de clorofila: fluorescência do fotossistema II, são essenciais para medir as reações de plantas a condições de estresse. Para auxiliar na padronização dos parâmetros para os índices de clorofila de clorofilas a, b e total e a fluorescência do fotossistema II (Fv / Fm), que são indicadores fisiológicos de condições de estresse, mudas de 6 meses de idade, de Persea americana Mill. Cv. 'Duke7' e 'Toro canyon' foram avaliadas sob condições casa de vegetação. Para cada planta, índices de clorofila foram medidos da segunda até a décima quarta folha completamente expandida. A fluorescência foi medida na terceira, quinta, sétima e nona folha totalmente expandida, e determinada em função do tempo e intensidade de exposição à fonte de luz, assim como do tempo para pré-adaptação da folha no escuro; também foram comparados entre o lado direito e esquerdo das folhas. Os índices de clorofila não foram diferentes entre os lados direito e esquerdo das folhas, mas foram entre diferentes variedades com 'Duke 7' tendo o valor mais alto a partir da oitava folha, enquanto que as de 'Toro canyon' não mostraram diferença. Para Fv/Fm, houve interação entre os três fatores em ambas as cultivares. $\mathrm{O}$ tempo prolongado de exposição (nove segundos), tempo curto para aclimatação no escuro, e baixa intensidade de exposição não induziu níveis máximos de fluorescência. Em ambas as cultivares de abacate, $100 \%$ de exposição à intensidade máxima de luz durante 7 segundos, após 25 a 30 minutos de adaptação no escuro, foi a combinação mais adequada para a medição da eficiência fotossintética.

PALAVRAS CHAVE: Abacateiro. Índice de clorofila. Fv/Fm. Fotosistema II. Parâmetros fisiológicos.

\section{REFERENCES}

ALVES, P. L. DA C. A.; MAGALHÃES, A. C. N.; BARJA, P. R. The Phenomenon of Photoinhibition of Photosynthesis and Its Importance in Reforestation. The Botanical Review, v. 68, n. 2, p. 193-208, Apr. 2002. https://doi.org/10.1663/0006-8101(2002)068[0193:TPOPOP]2.0.CO;2

ASHRAF, M.; HARRIS, P. J. C. Photosynthesis under stressful environments: An overview. Photosynthetica, v. 51, n. 2, p. 163-190, 15 Mar. 2013. https://doi.org/10.1007/s11099-013-0021-6

ASHWORTH, V. E. T. M. Microsatellite Markers in Avocado (Persea americana Mill.): Genealogical Relationships Among Cultivated Avocado Genotypes. Journal of Heredity, v. 94, n. 5, p. 407-415, 1 Sep. 2003. https://doi.org/10.1093/jhered/esg076

BAKER, N. R. Applications of chlorophyll fluorescence can improve crop production strategies: an examination of future possibilities. Journal of Experimental Botany, v. 55, n. 403, p. 1607-1621, 16 Jul. 2004. https://doi.org/10.1093/jxb/erh196 
BAKER, N. R. Chlorophyll fluorescence: a probe of photosynthesis in vivo. Annual review of plant biology, v. 59, p. 89-113, Jan. 2008. https://doi.org/10.1146/annurev.arplant.59.032607.092759

BJÖRN, L.; PAPAGEORGIOU, G. C.; BLANKENSHIP, R. A viewpoint: why chlorophyll a? Photosynthesis research, v. 99, n. 2, p. 85-98, 2009. https://doi.org/10.1007/s11120-008-9395-x

BUCHNER, O.; KARADAR, M.; BAUER, I.; NEUNER, G. A novel system for in situ determination of heat tolerance of plants: first results on alpine dwarf shrubs. Plant methods, v. 9, n. 1, p. 7, Jan. 2013. https://doi.org/10.1186/1746-4811-9-7

CHAVES, M. M. Environmental constraints to photosynthesis in ex vitro plants. In: Physiology, Growth and Development of Plants in Culture. Dordrecht: Springer Netherlands, 1994. p. 1-18.

https://doi.org/10.1007/978-94-011-0790-7_1

DOUHAN, G. W.; FULLER, E.; MCKEE, B.; POND, E. Genetic diversity analysis of avocado (Persea americana Miller) rootstocks selected under greenhouse conditions for tolerance to phytophthora root rot caused by Phytophthora cinnamomi. Euphytica, v. 182, n. 2, p. 209-217, 17 Apr. 2011.

https://doi.org/10.1007/s10681-011-0433-y

GABOR, B. K. Comparison of Rapid Methods for Evaluating Resistance to Phytophthora cinnamomi in Avocado Rootstocks. Plant Disease, v. 75, n. 2, p. 118, 1991. https://doi.org/10.1094/PD-75-0118

GEORGE, A. Resistance of the Duke Variety of Avocado to Phytophthora Root Rot. Calif. Avocado Soc. Yearbook, v. 40, p. 169-173, 1956.

HALL, D. O.; RAO, K. Photosynthesis. 6th. ed. Cambridge: Press syndicate of the university of Cambridge, 1999.

KHACHIK, F.; BEECHER, G. R.; WHITTAKER, N. F. Separation, identification, and quantification of the major carotenoid and chlorophyll constituents in extracts of several green vegetables by liquid chromatography. Journal of Agricultural and Food Chemistry, v. 34, n. 4, p. 603-616, Jul. 1986.

https://doi.org/10.1021/jf00070a006

MANDEMAKER, A. J. Review : Photosynthesis of avocado. New Zealand Avocado Growers Association Annual Research Report, v. 7, p. 1-10, 2008.

MARTÍNEZ-FERRI, E.; ZUMAQUERO, A.; ARIZA, M. T.; BARCELÓ, A.; PLIEGO, C. Nondestructive Detection of White Root Rot Disease in Avocado Rootstocks by Leaf Chlorophyll Fluorescence. Plant Disease, v. 100, n. 1, p. 49-58, Jan. 2016. https://doi.org/10.1094/PDIS-01-15-0062-RE

MATSUBARA, S.; CHEN, Y.-C.; CALIANDRO, R.; GOVINDJEE; CLEGG, R. M. Photosystem II fluorescence lifetime imaging in avocado leaves: contributions of the lutein-epoxide and violaxanthin cycles to fluorescence quenching. Journal of photochemistry and photobiology. B, Biology, v. 104, n. 1-2, p. $271-$ 284, 2011. https://doi.org/10.1016/j.jphotobiol.2011.01.003

MENGE, J. A.; DOUHAN, G. W.; MCKEE, B.; POND, E.; BENDER, G. S. Three New Avocado Rootstock Cultivars Tolerant to Phytophthora Root Rot : "Zentmyer", "Uzi ", and "Steddom ." HortScience, v. 47, n. 8, p. 1191-1194, 2012.

MORENO, S. G.; VELA, H. P.; ALVAREZ, M. O. S. La fluorescencia de la clorofila a como efectos tóxicos en el aparato fotosintético de plantas y algas. Revista de Educación Bioquimica, v. 27, n. 4, p. 119-129, 2008.

OQUIST, G.; WASS, R. A portable, microprocessor operated instrument for measuring chlorophyll fluorescence kinetics in stress physiology. Physiologia Plantarum, v. 73, n. 2, p. 211-217, Jun. 1988. https://doi.org/10.1111/j.1399-3054.1988.tb00588.x 
OUMA, G. Morphological and Physiological Parameters of Avocado (Persea americana) Rootstock Seedlings as Affected by Different Container Sizes and Different Levels of Irrigation Frequency. Journal of Biological Sciences, v. 7, n. 6, p. 833-840, 1 Jun. 2007. https://doi.org/10.3923/jbs.2007.833.840

OYARCE, P.; GUROVICH, L. Electrical signals in avocado trees: responses to light and water availability conditions. Plant signaling \& behavior, v. 5, n. 1, p. 34-41, Jan. 2010. https://doi.org/10.4161/psb.5.1.10157

PAPAGEORGIOU, G. Chlorophyll a Fluorescence. Dordrecht: Springer Netherlands, 2004. v. 19 https://doi.org/10.1007/978-1-4020-3218-9

https://doi.org/10.1007/978-1-4020-3218-9_26

https://doi.org/10.1007/978-1-4020-3218-9_2

PAPAGEORGIOU, G.; TSIMILLI-MICHAEL, M.; STAMATAKIS, K. The fast and slow kinetics of chlorophyll a fluorescence induction in plants, algae and cyanobacteria: a viewpoint. Photosynthesis Research, v. 94, n. 2-3, p. 275-290, 5 Dec. 2007. https://doi.org/10.1007/s11120-007-9193-x

PLOETZ, R. C.; SCHAFFER, B. Effects of flooding and Phytophthora root rot on photosynthetic characteristics of avocado. Proceedings of Florida State Horticulture Society. Anais...Florida: 1987

REED, S.; SCHNELL, R.; MOORE, J. M.; DUNN, C. Chlorophyll a + b Content and Chlorophyll Fluorescence in Avocado. Journal of Agricultural Science, v. 4, n. 4, p. 29-36, 2 Feb. 2012. https://doi.org/10.5539/jas.v4n4p29

RICHARDSON, A. D.; DUIGAN, S. P.; BERLYN, G. P. An evaluation of noninvasive methods to estimate foliar chlorophyll content. New Phytologist, v. 153, n. 1, p. 185-194, 11 Jan. 2002.

https://doi.org/10.1046/j.0028-646X.2001.00289.x

SARWAT, M.; AHMAD, A.; ABDIN, M. Z. Stress Signaling in Plants: Genomics and Proteomics

Perspective, Volume 1. Ilustrada ed. New York, NY: Springer New York, 2013. v. 1

SCHAFFER, B.; GIL, P. M.; MICKELBART, M. V.; WHILEY, A. W. Ecophysiology. In: SCHAFFER, B.; WOLSTENHOLME, B. N.; WHILEY, A. W. (Eds.). . The avocado: botany, production and uses.

Wallingford: CABI, 2013. p. 168-199. https://doi.org/10.1079/9781845937010.0168

https://doi.org/10.1079/9781845937010.0000

SCHAFFER, B.; WHILEY, A. W. Environmental regulation of photosynthesis in avocado trees-A minireview. V World Avocado Congress. Anais...2003

SCORA, R. W.; BERGH, B. The origins and taxonomy of avocado (Persea americana) mill. Lauraceae. Acta Horticulturae, v. 275, p. 387-394, Jul. 1990. https://doi.org/10.17660/ActaHortic.1990.275.47

STAUFFER, R. D. Avocado tree, 21 Jan. 1986.

TAIZ, L.; ZEIGER, E. Photosynthesis: Carbon reactions. In: ASSOCIATES, S. (Ed.). . Plant Physiology. 5. ed. Armed: Sinauer Associates, Inc, 2010. p. 782.

VAZ, J.; SHARMA, P. K. Relationship between xanthophyll cycle and non-photochemical quenching in rice (Oryza sativa L.) plants in response to light stress. Indian journal of experimental biology, v. 49, n. 1, p. 60 7, 1 Jan. 2011.

WENG, J.-H.; LAI, M.-F. Estimating heat tolerance among plant species by two chlorophyll fluorescence parameters. Photosynthetica, v. 43, n. 3, p. 439-444, Sep. 2005. https://doi.org/10.1007/s11099-005-0070-6

WOLSTENHOLME, B. N. Avocado rootstocks : What do we know; are we doing enough research ? 2003. 
WOLSTENHOLME, B. N.; WHILEY, A. W. Ecophysiology of the avocado (Persea americana mili .) tree as a basis for pre-harvest management. Revista Chapingo Serie Horticultura, v. 5, p. 77-88, 1999.

ZLATEV, Z. Drought-Induced Changes in Chlorophyll Fluorescence of Young Wheat Plants. Biotechnology \& Biotechnological Equipment, v. 23, n. sup1, p. 438-441, 15 Apr. 2014. 